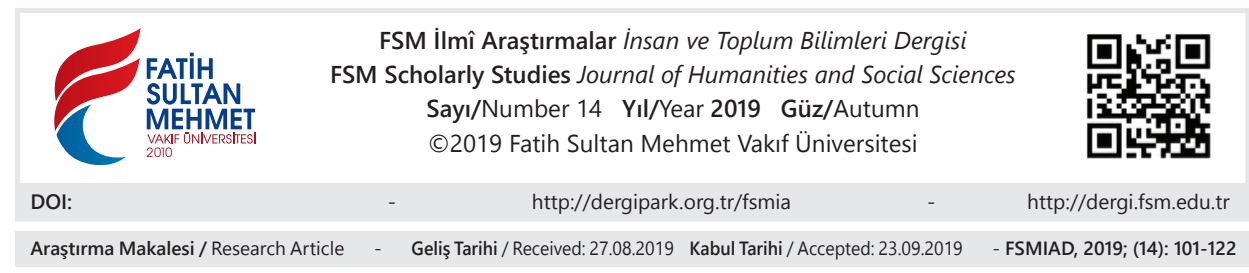

\title{
Sabahattin Ali, Sait Faik ve Mustafa Kutlu Hikâyelerinde Anlatıcı-Okur Tiplerinin Benzerlikleri ve Farklılıkları
}

\author{
A. Ali Ural ${ }^{*}$
}

\section{$\ddot{O} \mathbf{z}$}

Çalışmanın ağırlık noktası, Türk hikâyeciliğinin üç önemli ismi olan Sabahattin Ali, Sait Faik ve Mustafa Kutlu'nun, hikâyelerini aktarmak üzere seçtikleri anlatıcıları incelemek, ulaşmayı hedefledikleri okur tiplerini tespit edebilmek ve her üç hikâyecinin bu bağlamda benzerliklerini ve farklılıklarını ortaya koyabilmektir. Bütün hikâyelerinin incelenmesinden sonra özellikle Sait Faik ve Mustafa Kutlu için mevcut anlatıcı ve okur tipolojisinin dışında birtakım anlatıcı ve okur tipleri tasarladıkları görülmektedir. Onlar için yeni tanımlar önerilmeye çalışılmıştır.

Anahtar Kelimeler: Sabahattin Ali, Sait Faik, Mustafa Kutlu, anlatıc1, okur.

* Doktora Öğrencisi, Fatih Sultan Mehmet Vakıf Üniversitesi Lisansüstü Eğitim Enstitüsü Türk Dili ve Edebiyatı Anabilim Dalı, İstanbul/Türkiye, aliural@hotmail.com, orcid.org/00000002-7248-9357 


\title{
Similarities and Differences Between Reader-Narrator Types in the Short Stories of Sabahattin Ali, Sait Faik and Mustafa Kutlu
}

\begin{abstract}
The main focus of the study is to examine the narrators chosen by three prominent Turkish short story writers: Sabahattin Ali, Sait Faik and Mustafa Kutlu and identify the types of readers they target in their stories, revealing the similarities and differences between the three authors regarding the subject. After all the stories have been examined, it is revealed that, especially in the case of Sait Faik and Mustafa Kutlu, certain types of narrators and target readerships have been conceived of by the authors which stand outside the existing typology. The study aims to propose new definitions for these new varieties.
\end{abstract}

Keywords: Sabahattin Ali, Sait Faik, Mustafa Kutlu, narrator, reader. 


\section{Giriş}

Her yazar, eserini okuruna aktaracak bir anlatıcı belirler. Kendisi doğrudan metnin içerisinde yer alamayacağından bir aracı kurgulamak zorunda kalır. İşte bu aracının adı anlatıcıdır. O, yazar tarafından tasarlanan dünyada "tasarlanmış" bir kişi/varlıktır. Diğer bir deyişle "anlatıcı ve anlatı kişileri temelde 'kâğı üzerinde var olan' varlıklardır; bir anlatının somut olarak var olan yazarı, bu anlatının anlatıcısıyla hiçbir şekilde karıştıılamaz."

Yazar, anlatıcısına bir bakış açısı belirlemektedir. Hangi şahıs kipiyle, kurmaca dünyanın içinde mi dışında mı yer almalı, anlatıyı nasıl bir üslupla aktarmalı gibi sorular, yazarın eserini kaleme almaya başlamadan önce cevaplaması gereken sorulardir.

Anlatıcı tipolojisi² yazara birtakım imkânlar sunmaktadır. Bir yandan tanrısal anlatıcı, ben-anlatıcı, çoğul anlatıcı gibi birçok seçenekle, eser bir nevi sesine kavuşurken diğer yandan hedef kitlesi olan okur tipi oluşmaktadır. Nitekim her yazarın bazen örtülü bazen de son derece açık şekilde bir okur tipini tasarladıkları ve ona doğrudan hitap ettikleri görülmektedir.

Çalışmada ele alınan Sabahattin Ali, Sait Faik ve Mustafa Kutlu gerek seçtikleri anlatıcılarla gerekse kurguladıkları okurlarla Türk hikâyeciliği içerisinde kendilerine has bir yol çizmektedirler. Üç hikâyecinin benzerliklerinin yanı sıra farklılıklarının da ortaya konmaya çabalandığı bu çalışmada bazı yeni anlatıcı ve okur tipleri de önerilmeye çalışılmıştır.

\section{Hikâyelerdeki Anlatıcı Benzerlikleri ve Farklılıkları}

Sabahattin Ali, Sait Faik ve Mustafa Kutlu'nun benzer anlatıcılar olarak "tanrısal anlatıcı", "ben-anlatıcı", "yazar-anlatıcı" ve çerçeve anlatıların "dış-iç anlatıcı"larını kullandıkları görülmektedir. Üçüncü tekil şahısla yazdıkları hikâyeler, büyük oranda tanrısal anlatıcı tarafından aktarılmaktadır. Anlatıyı kuş bakışı gözlemleyebileceği bir yere konuşlanmış olan bu anlatıcı, aynı anda her şeyi görebilmekte, sadece göz önünde olanları değil, karakterlerin zihninden geçirdiklerini ve geçmiş-gelecek çizgisi üzerinde yer alan bütün olayları bilmektedir. ${ }^{3}$

1 Roland Barthes, Anlatıların Yapısal Çözümlemelerine Giriş, çev. Mehmet Rifat-Sema Rifat, İstanbul, Gerçek Yayınevi, 1988, s. 54.

2 Bu konuda ayrıntılı bir çalışma için bkz. Yavuz Demir, İlk Dönem Türk Hikâyelerinde Anlatıcılar Tipolojisi, İstanbul, Dergâh Yayınları, 2002.

$3 \mathrm{Bu}$ anlatıc1 tipleri ve anlatı teknikleri hakkında, bkz. Mehmet Tekin, Roman Sanatt-Romanın Unsurları I, İstanbul, Ötüken Yayınları, 2001; Philip Stevick, Roman Sanatı, çev. Sevim Kantarcıoğlu, Ankara, Akçağ Yayınları, 2017; E. M. Forster, Roman Sanatı, çev. Ünal Aytür, İstanbul, Milenyum Yayınları, 2019. 
Üç hikâyecide benzerlik olarak "ben-anlatıcı" dikkati çekmektedir. Özellikle Sait Faik ve Mustafa Kutlu'nun (sayıca Sabahattin Ali' den çok daha fazla hikâye yazmışlardır) "ben-anlatıcı"yı sıkça kullandıkları görülmektedir. "Ben-anlatıcı", yazarın en rahat hikâye aktartacak anlatıcısıdır. Birinci tekil şahısla yazıldığg için yazar, kendisini çok daha kolay ve rahat anlatıcının rolüne büründürebilir fakat okur da bu sebepten dolayı "ben-anlatıcı"yı çok daha hızlı bir şekilde yazarla örtüştürebilmektedir. "Ben-anlatıcı"nın kullanıldığı hikâyelerde, kurgusal bir anlatıc1 alg1sı oluşturmak daha zordur, çünkü buradaki "ben" kalıbı, doğrudan yazarın kendisini işaret edebilmektedir. Bu anlatıcının kullanıldığı hikâyelerde aynı zamanda yazar-anlatıcı tipi de ortaya çıkmaktadır.

Sabahattin Ali, Sait Faik ve Mustafa Kutlu, okurun gözünde anlatıcı olarak kendilerinin görülmesinden endişe duymamışlardır. Hikâyelerin, bu sayede, yazarların birebir gözlemleri oldukları hissi ağır basmaktadır. Ayrıca anlatıcıya verdikleri isimler, vasıflar, yazarın kendi kimliğiyle birebir örtüşmektedir.

Her üç hikâyecinin de kullandığı bir anlatıcı tipi de "dış-iç anlatıcı"dır. Bu anlatıcılar, çerçeve hikâyelerin asli ögeleridir. Adından anlaşıldığı üzere çerçeve olarak ortaya çıkan hikâyenin içinde yeni bir çerçeve oluşturulmakta, ana hikâyeden ayrı bir hikâye daha anlatılmaktadır. Ana hikâyeyi aktaran anlatıcı "dış anlatıcı", hikâyenin içindeki yeni hikâyeyi aktaran anlatıcı "iç anlatıcı"dır. Çerçeve hikâyeler "mimesis" düsturunun yani tabiatın birebir taklit edilmesinin hikâyedeki yansımalarıdır denilebilir. ${ }^{4}$ Çünkü gerçek hayat, içinde sayısız hikâye barındırmaktadır. Örneğin iki yabancı dahi bir araya gelip konuştuklarında asıl konularıyla bağlantılı olabileceğini düşündükleri bağımsız hikâyeler anlatabilmektedirler. Bu nedenle çerçeve hikâyelerinin "mimesis"in, hikâyedeki gölgesi olduğunu söylemek yanlış olmaz.

Türk hikâyeciliğinin ilk dönemlerinde -henüz kurmacanın edebiyatı ele geçirmediği dönemlerde- çerçeve hikâye daha sıklıkla görülmektedir. Maupassant tarzı yazarlığın, çerçeve hikâyenin bir zamanlar dünya edebiyatında yaygıın hale gelmesindeki rolü yadsınamaz. $^{5}$

4 "Mimesis" hakkında bkz. Aristoteles, Poetika, çev. İsmail Tunalı, İstanbul, Remzi Kitabevi, 2002; Ahmet Cevizci, Felsefe Terimleri Sözlügü̈, İstanbul, Paradigma Yayınları, 1999, s. 596597; Pelin Şen, "Platon'un Mimesis Kavramı Üzerine Bir İnceleme”, Eskişehir, AÖF, 2012; Muharrem Hafiz, "Platon, Aristoteles ve Plotinus'ta Mimesis Teorisi”, Journal of Islamic Research, 26(1), 2015; İbrahim Uzun, “Aristoteles'in Katharsis Ve Mimesis Kavramlarının Analizi ve Değerlendirilmesi”, https:// www.academia. edu/ 5688285/ aristotelesin_katharsis_ve_ mimesis_kavramlarının_analizi_ve_değerlendirilmesi”. Erişim tarihi: 20.09.2019.

5 "Hikâye/ Sosyal Gerçekçiler", Cumhuriyet Dönemi Türk Nesri, Ortak Kitap, Eskişehir, AÖF, 2015. 
Sabahattin Ali’nin özellikle "Değirmen" isimli hikâyesinde geçen "Dinle adaşım, sana bir Çingene'nin aşkını anlatayım”, Sait Faik’in "Sana bir başka hikâye anlatayım" "ve Mustafa Kutlu'nun hikâye içinde hikâye anlatan sayısız örneği, çerçeve hikâyelerinin belirgin işaretlerindendir.

Sabahattin Ali'nin ("Çaydanlık” hikâyesi) ve özellikle Sait Faik'in birkaç hikâyesinde ("Park", "Sarnıç" hikâyeleri) bir "ben-anlatıcı", hikâye ilerledikçe ortaya çıkmaktadır. Sait Faik adı geçen hikâyelerde üçüncü tekil şahısla başlattığı anlatıyı, bir yerden sonra ortaya çıkardığı "ben-anlatıcısı"na devretmekte, bu değişim, yazar ve anlatıcının aynı kişi olduğu hissini kuvvetlendirmektedir. Hikâye peşinde sıkça dolaştığı bilinen Sait Faik'in ayağına hikâyenin geldiği ve anlatıcının tek yapması gerekenin, olayı gözlemlemek ve okurlara aktarmak olduğu hissedilmektedir. Böylece yazar, bir anlatıcı olarak belirli bir mesafeden olanları izleyip aktarmaktadır. Sait Faik'in bilhassa "İhtiyar Talebe" isimli hikâyesi bu bağlamdaki hikâyelere örnek teşkil etmektedir. Bu da devreye "gözlemci anlatıcı"yı sokmaktadır. "Gözlemci anlatıcı", hikâyenin ana karakteri değildir; o yalnızca ana hikâyenin şahidi olarak orada bulunan kişilerden biridir. Bu tür hikâyelerde birinci tekil şahıs kipiyle hikâyeyi anlatsalar da asli karakter kadrosunda yer almamaktadır. Örneğin Mustafa Kutlu'nun "Uç Selahattin Uç” hikâyesi her ne kadar hikâye "ben" diliyle anlatılsa da buradaki ben-anlatıcı bir gözlemci anlatıcıdır. Sabahattin Ali'nin "Çaydanlık" hikâyesinde de yine aynı özelliklere sahip gözlemci bir anlatıcı ortaya çıkmaktadır.

Sait Faik hikâyelerinin bazılarında geç ortaya çıkan bir "ben-anlatıcı" mevcuttur. Özellikle "Orman ve Ev" adlı hikâyesinde bu vasıf gözlemlenmektedir. Başka bir örnek olarak "Üçüncü Mevki” adlı hikâyesini ele alınabilir. "Ben-anlatıcı", metin ilerledikten sonra "Ben uyuyor muydum?" cümlesiyle ortaya çıkmaktadır. O ortaya çıkana kadar hikâye üçüncü tekil şahıs ağzından aktarılmıştır. "Plaj İnsanları" hikâyesinin ortalarında da "İște o zaman tesadüf ben de sandal iskelesindeydim" cümlesiyle bir "ben-anlatıcı" ortaya çıkmaktadır. "Mahpus" isimli hikâyede de anlatının ortalarına doğru bakış açısı değişmektedir. Üçüncü tekil kalıbıyla anlatılan hikâye "Bütün şehir halkı, acayip acayip, dükkânların önüne çıkarak, kahvelerden firlayarak bu garip olaya baktık" ${ }^{10}$ cümlesinin geçmesinden sonra yeni bir anlatıciya devrolunmaktadır.

6 Sabahattin Ali, Değirmen, İstanbul, Yap1 Kredi Yayınları, 2017, s. 14.

7 Sait Faik, Tüneldeki Çocuk, İstanbul, İş Bankası Yayınları, 2016, s. 50.

8 Sait Faik, Semaver, İstanbul, İş Bankası Yayınları, 2018, s. 73.

9 Sait Faik, Sarnıç, İstanbul, İş Bankası Yayınları, 2017, s. 102.

10 Sait Faik, Şahmerdan, İstanbul, İş Bankası Yayınları, 2017, s. 34. 
Sabahattin Ali ve Sait Faik arasındaki bu benzerlik, Mustafa Kutlu'da başka bir şekil almaktadır. Onun hikâyelerinde geçen "ben-anlatıcı"ların tamamını yazarın kendisiyle bağdaştırmak mümkün değildir. Elbette yazara atıfta bulunanlar mevcuttur, fakat bunlar azınlıktadır. Uzun hikâyeler kaleme aldığı için bazen tek bir anlatıcı yetersiz kalmaktadır. Karakterlerin kendi ağzından hikâyeyi aktardığı zaman ortaya çıkan "ben-anlatıcı", çoğu zaman "yazar-anlatıcı" hükmünü yitirmektedir.

Mustafa Kutlu'nun sonraki yıllarında daha çok başvurduğu uzun hikâye yazma meyli, zaman zaman roman yoluna girmesi sebebiyle, birkaç anlatıcının ortaya çıkmasına sebep olmaktadır. Bazen karakterlerin ağzından bazen ilahî bakış açısıyla anlatılan hikâye, kimi zaman çoğul anlatıcı hüviyeti kazanmaktadır. Sevincini Bulmak ve Beyhude Ömrüm gibi eserlerinde bu anlatıc tipinin örneklerini görmek mümkündür. Buralarda ortaya çıkan çoğul anlatıcı tipini Sait Faik’te de gözlemlemek mümkündür. "İhtiyar Talebe" adlı uzun hikâyesinde bu yöntemi kullandığı gibi, son derece kısa olan bazı hikâyelerinde de kullanmıştır -ki bu, kısa hikâyede kolay uygulanabilir bir yöntem değildir. Sait Faik "Kestaneci Dostum" ve "Bir Define Avcısı" isimli pek de uzun olmayan hikâyelerini birden fazla anlatıcıyla aktarmayı başarmaktadır.

“Çoğul anlatıcı”ya Sait Faik ve Mustafa Kutlu'da rastlamak mümkünken Sabahattin Ali' de görülmez. Çerçeve anlatılarda kullandığı dış ve iç anlatıcı dışında onun hikâyelerinde böylesi bölünmeler görülmemektedir. Sabahattin Ali hikâyeciliği, diğer iki hikâyeciyle kıyaslandığında son derece disiplinli ve programlıdır. Hikâyeler savrulmadan, sürpriz bir anlatıcı ortaya çıkarmadan ya da ansızın okurla konuşmadan kurulmuş ve tasarlanmış hikâyelerdir. Dolayısıyla onun hikâyelerinde gelişigüzelliğe rastlamak pek mümkün değildir.

Sabahattin Ali'de anlatıcılar son derece açık ve yalınken Sait Faik ve Mustafa Kutlu'da bazen girift şekillere bürünmektedirler. Örneğin Sait Faik'te ara sıra görülen güvenilmez anlatıcı, hikâyeyi başka bir boyuta taşımaktadır. Anlatıcının, hikâyeyi istediği gibi evirip çevirmesi, bir söylediğini daha sonra inkâr edip başka bir şey söylemesi, bu anlatıcı tipinin en bariz özelliğidir:

"Panco, Çilek isimli bir sokakta oturur. Futbol oyunları görür rüyasında. Yahut da yine rüyasında pişpirik oynar. Ben gece yarısından sonra yağmurlu bir havada Atikali'deyim. Sözüm ona bir bulvar üstündeyim. Yürüyorum. Yağmur yağıyor da yağıyor. Evet, yağmurun, yalnızlığın, Atikali'nin hakk1 var: Uzaklaştıkça anamı, Panco'yu, köpeğim Arap'ı daha çok özlüyorum. Üçü de uykudadır. Annem horluyor, Arap uyanmış, sokağa kulak veriyor, Panco rüya da görmüyor, demincek attım."”1

11 Sait Faik, Alemdağ' da Var Bir Yılan, İstanbul, İş Bankası Yayınları, 2014, s. 12-. 
"Hikâyeyi böylece bitirebilirim. Benim bitirişlerimden biri olur. Olmasına olur ama hayır. Ne çarşıya çıkıyor, ne bembeyaz kahveye giriyor, görmek istemediğimin karşısına geçiyor, ne de kahveciyle konuşuyorum. Evimde, odamdayım. Çarşıya inemem. Otuz dokuz derece ateşim var. Üşüyor, titriyorum. Bir ara yanıyorum. Anam sirke koyuyor. Okuma artık yat, diyor. Işığı söndürüp gidiyor. Etrafı dinliyorum. Kaşıkadası'nın köpeği hâlâ havlıyor. Rüzgâr camları dövüyor ve kapıları sarsıyor. Işığı yakıyorum... Bu da bir bitiriş şekli ama bu da değil. Değil, bu da değil. Çarşıya inemem, o kadar."12

Her iki alıntıda da görüldüğü üzere anlatıcı, bir gerçeklik oluşturmakta ve tam buna inandırmışken fikrini değiştirip daha önce söylediğini yalanlayarak güvenilmezliğini ortaya koymaktadır. Bu tip anlatıcı, hikâyeyi muğlak bir hâle getirdiği gibi, ona sağlam bir omurga da oluşturmamaktadır. Yazarın, bu eylemden habersiz olduğu düşünülemez. Nitekim iki seçenek ortaya çıkmaktadır: Yazar, ya savrukluğunun kurbanıdır ya da sanat yapma gayesiyle, inandırıcılığı zedelemek pahasına böyle davranmaktadır. Her iki durumun da yazarın lehine olduğunu kabul etmek güçtür. Güvenilmez anlatıcının emarelerini Mustafa Kutlu hikâyelerinde nadiren de olsa görmek mümkündür:

'Sefa Oteli'nin meydana bakan üst kat pencerelerinden bir genç adam dürbünle bu yükleme işini gözetler. Genç adam, kimdir, nedir, ne iş yapar, niçin olup bitenleri dürbünle dikizlemektedir.

Bilmiyoruz. Evet... Kıllı kasabın niçin keman çaldığını bilmediğimiz gibi; tanımadığımız, yakışıklı, şık giyimli bu genç adam hakkında da şimdilik bir bildiğimiz yok."13

Başka bir örnekte benzer bir tutum gözlemlenmektedir:

"Dışarıda yağmur dinmişti. Tertemiz havayı kokladım. Islak toprak, at fışkısı, biraz da lavanta kokuyordu. Yok yok, bu lavantayı ben ekledim. Kafam yerinde değil." ${ }^{14}$

Sait Faik ve Mustafa Kutlu için ortak bir anlatıcı tipi olarak "meddah anlatıcı" önerilebilir. Her iki hikâyeci de okurlarıyla sohbet etmekten son derece büyük zevk almaktadırlar. ${ }^{15}$ Çeşitli şekillerde ortaya çıkan bu sohbetlerde bazen

12 A.g.e., s. 102.

13 Mustafa Kutlu, Mavi Kuş, İstanbul, Dergâh Yayınları, 2017, s. 24.

14 Mustafa Kutlu, Ortadaki Adam, İstanbul, Dergâh Yayınları, 1970, s. 62.

$15 \mathrm{Bu}$, yazarın kendi okurunu tasarlamasının bir göstergesidir. Bu hususta bazı dikkatler için bkz. Bahtiyar Aslan, "Mustafa Kutlu Hikâyelerinde Yazar-Anlatıcı ve Okuyucu Diyaloğunun İşlev- 
okur adına soru sorulmakta, bazen onun adına karakterle çatışılmakta, bazen onun adına yazarla çatışılmakta ve bazen de yazar onunla yalnızlığını paylaşmaktadır. "Meddah anlatıcı" işte bu tavırlar söz konusu olduğunda ortaya çıkan anlatıcı olarak önerilebilir. Kahvelerde hikâye anlatan ve bunu alevlendirmek için dinleyenlerle konuşan ya da onlara soru soran meddah geleneğinden ismini alabilecek bu anlatıcı tipi, hem Sait Faik hem de -ve özellikle- Mustafa Kutlu hikâyeciliği için son derece uygundur. Hele ki "Efendim" hitabıyla, "Anlatalım" ya da "Söyleyelim" sözleriyle konuları anlatması, meddah geleneğiyle birebir örtüşmektedir.

"Meddah anlatıcı" devreye girdiğinde iki taraflı bir canlanma söz konusudur. Yazar, eserini kaleme alırken okuruna görünmek istemektedir ve okur da pasif bir okuyuculuktan silkinip kendisine gelmektedir. Kurmacanın ihlali söz konusu olsa da yazarlar bunu göze almaktadırlar. Okur, yazarın kendisiyle; yazar da okurun kendisiyle sohbet ettiği veya birbirlerini görebildikleri inancına kapılır. $\mathrm{Bu}$ durumda anlatı canlanır, ancak kurmaca hasar alır.

"Evler mi? diye sormayın. Evet, evler... Bunları bildiğim halde eskiden merak ettiğim Kınalı'nın evlerini şimdi büsbütün görmeye can atıyorum. ... Bir masa düşünelim. Eskimiş muşambadaki boncuklu bir nihalin üzerine bir sahan konuyor. Bu et midir, sebze midir? Haydi bu meraktan cayalım. Farz edelim ki, ettir." 16

Soru karşısında her insanın geliştirdiği ortak bir tepki vardır: Cevap vermek. Sait Faik de Mustafa Kutlu da meddah anlatıcıları sayesinde sıç̧a soru sorma yöntemini kullanmaktadırlar. Okur, ister istemez sorunun muhatabı olarak kendisini görecek ve Sait Faik'in dediği gibi "okuyucu bir nevi yazmayan yazıc1"17 özelliğiyle hikâyeyi zihninde yazmaya başlayacaktır. Artık yazarla okur arasında bir iş birliği yapılmış demektir ve okur, en azından yazar kadar bu hikâyeyi sahiplenmektedir. Benzer tavrı Mustafa Kutlu'da da görmek mümkündür:

“Buna bir de yaşını ekleyin. Evet, 'çekilmez' diyeceksiniz değil mi? Hayır, Doktor Yahya bütün bu sevimsiz tarafları yanında dünya tatlısı bir adamdır. Sabırlı, nüktedan, müşfik, merhametli.

Ya, az önce 'çekilmez' diyordun.

lerinden Biri: Yazarın Kendi Okuyucusunu Yaratması", içinde: Aynanın Strrı: Mustafa Kutlu Sempozyum Bildirileri, İstanbul, 2012; Serhat Demirel, "Modern Türk Şiirinde Okur Algıları (1860-1940)", (Yayımlanmamış Doktora Tezi), SAÜ, SBE, Sakarya, 2019.

16 Sait Faik Abasıyanık, Mahalle Kahvesi, Ankara, Bilgi Yayınevi, 2000, s. 61-62.

17 Hilmi Yücebaş, Bütün Cepheleriyle Sait Faik: Hayatı/Hatıraları/Eserleri, İstanbul, İnkılâp Kitabevi, 1964, s. 69. 
Hayır aziz okuyucu, onu sen diyorsun. Ben bir insanı anlamanın zor olduğunu söylüyorum.”18

Olası bir sohbet havası yaratılmakta, okur daha farkına varmadan kendisini bir tartışmanın içinde bulmaktadır. Burada sorulması gereken soru, okurun bir nevi rızası olmadan böylesi bir konuya dâhil edilmekten hoşlanıp hoşlanmayacağıdır. Bunu Mustafa Kutlu'nun da düşündüğü, cümleleriyle açığa çıkmaktadır: "Ey okur! Bu şöhreti dünyayı tutmamış, tanınmamış etmemiş, kendi halindeki adamın hayatı işte karşınızda. İster okuyun, isterseniz 'Ya, ne var bunda, ortalama bir adam işte, gözüme yazık' deyip bırakın. Karar sizin." 19

Özellikle Mustafa Kutlu'da ortaya çıkan ve “öğretmen anlatıcı” olarak önerilebilecek anlatıcının, bir yönüyle Sait Faik hikâyelerinde de ortaya çıktığını söylemek mümkündür. Mustafa Kutlu bu anlatıcısı aracılığıyla bir öğretmen gibi -bir zamanlar mesleği olan öğretmenlikten kalma alışkanlıkla- okurunu eğitmekte ve bilgisini anlatıcı aracıllğıyla okuruna aktarmaktadır: "Postacı yeniden eski Postacı olmuştu. Sorarım sana ey okur, biz bunu böyle yazdık diye Postacı eski Postacı olabilir mi? Aferin sana. Olamaz tabii." ${ }^{20}$ Anlatıcının burada takındığ tavır, sözlüye öğrencisini kaldırmış öğretmen tavrıdır. Soruyu bildin manasında telaffuz edilen "Aferin” de bunun en kuvvetli işaretidir. Öğretmen anlatıcının özellikleri, Sait Faik’te de görülmektedir:

"Bundan sonraki kısmı, okuyucuya, 'Nasıl öğrenmiş bunları acaba?' diye sualler sordurarak yazıma devam edeceğim. Nasıl öğrendiğime gelince onu da söylemeyeceğim. Söylemeyeceğim ama yine şunları ilaveden de kendimi alamıyorum: Belki bu adamla aynı evde beraber yattık. Belki o adam benim demeyeceğim. Mesela size, 'Odasında başını kaşıdı' diye yazsam; 'Nereden biliyorsun, gördün mü?’ diye bana sorabilirsiniz. Yahut; 'Sabahleyin uyandığı zaman içinde bir yorgunluk duydu' desem ne gülünç bir cümle olur! Okuyucu bana 'Sen o adam mısın? Be herif! Herifin içini nereden biliyorsun?' diye sorabilir. Haklıdır da... Ben, şu hikâyemin devamınca aynı hataları yapmaya hazırlanıyorum, mazur görün! Bilmem size yazıya başlarken bu adamla olan müthiş iç akrabalığımı söylemiş miydim? Burada yine bir noktayı daha açıklamadan asıl konuya giremeyeceğim; o da bu hikâyenin içindeki adamın hem bana çok yakınlığıdır; hem de posta müvezziinin lakırdıları gibi başka insanların o adam hakkında bildiklerini de yazarsam o adamla benim aramda aynı zamanda

18 Mustafa Kutlu, Mavi Kuş, İstanbul, Dergâh Yayınları, 2017, s. 44.

19 Mustafa Kutlu, Anadolu Yakası, İstanbul, Dergâh Yayınları, 2017, s. 10.

20 Mustafa Kutlu, Menekşeli Mektup, İstanbul, Dergâh Yayınları, 2017, s. 27. 
hiçbir münasebetin bulunmadığını yazıyorum demektir. Bu böylece malum ola..."21

Yukarıdaki örnek, özellikle Sait Faik hikâyeciliği için son derece önemli bilgiler ihtiva etmektedir. Anlatıcısını -ama aslında kendini- okuruyla karşı karşıya getirerek yazarken zihninde hangi olası soruların belirdiğini ve bunları öncelikle kendisinin cevaplaması gerektiğini göstermektedir. Böylece yazarlığın en tehlikeli tuzaklarından biri olan mantık hatalarından kaçınılmış olmaktadır.

Mustafa Kutlu'daki tavır da aynıdır: "Şu anda yazacaklarımı Fahrettin Bey düşündü mü, düşünmedi mi bilmiyorum ama, bizim hikâyeci kafası onun eve gireceği anda düşündüklerini şöyle sıraladı..."22 "Bütün dükkânları saymayalım, adını verip geçelim. Zaten gayemiz ey sevgili okur, nasıl bir macera nakledeceğimizi anlatmadan önce nerede durduğumuzu, hangi insanlarla muhatap olduğumuzu göstermektir. Böylece kitabın hissiyatına ortak olursunuz belki." ${ }^{23}$ Buradaki ipuçları Mustafa Kutlu'nun hikâyeciliğinde mekân tasvirinin ne zaman ve ne ölçüde gerekli olduğunu göstermektedir. ${ }^{24}$

Sabahattin Ali'den ve Sait Faik'ten ayrı olarak Mustafa Kutlu'da dikkat çeken bir anlatıcı tipi daha teklif edilebilir: "Kışkırtan anlatıcı". Kutlu, okuruyla konuşmanın sınırlarını o kadar genişletmiştir ki, bu sohbetlerin dahi kendi içinde ayırıcı vasıfları ortaya çıkmaktadır: Karakterleri kışkırtan anlatıcı, okuru kışkırtan anlatıcı, anlatıcıyı veya yazarı kışkırtan okur şeklinde kendilerini hikâyelerde göstermektedirler. Karakteri kışkırtan anlatıcıya örnek bu tavrın işaretidir:

"Zamanı gelince direk sorarım. Sorar mısın? Ne münasebetle. Açık bir şey canım. Çocuk değiliz ya. Hissiyatımı dile getirebilirim. Ya karşılık bulamazsan. Doğru. Muhabbet iki başlı demişler. İşte o zaman Tepeköy’de kalmanın mânası kalmaz. Çabuk pes ettin be! Kim demiş." ${ }^{25}$

Mustafa Kutlu'da bu ani müdahaleler örnekteki gibi o kadar üst üste gelmektedir ki bazen konuşanın kim olduğunu anlamak güçleşmektedir. Karşılıklı bir konuşma şeklinde metin ilerlediği için bazen konuşanın yazar mı yoksa anlatıcı mı olduğu ayırt edilememektedir. Okuru kışkırtan anlatıcı, Mustafa Kutlu’nun kışkırtan anlatıcısının başka bir yönüdür:

21 Sait Faik Abasıyanık, Havada Bulut, İstanbul, İş Bankası Yayınları, 2016, s. 45-.

22 Mustafa Kutlu, Ortadaki Adam, İstanbul, Dergâh Yayınları, 1970, s. 70.

23 Mustafa Kutlu, Mavi Kuş, İstanbul, Dergâh Yayınları, 2017, s. 8.

24 Mustafa Kutlu öykücülüğünde mekân tasviri ve işlevi hakkında, örneğin, bkz. Bilal Can, "Mustafa Kutlu Öykücülüğünde Mekân: Bir Edebiyat Sosyolojisi İncelemesi” (Yayımlanmamış Yüksek Lisans Tezi), Dumlupınar Üniversitesi Sosyal Bilimler Enstitüsü, Kütahya 2015.

25 Mustafa Kutlu, Zafer Yahut Hiç, İstanbul, Dergâh Yayınları, 2016, s. 95. 
"Bırakın gitsin. Tası tarağı toplayıp gitsin. Önümüze planları, paftaları açalım. Bozkırı bir baştan bir başa sürelim. Nane, maydanoz ekelim. Şaşırmayın efendim... Evet, evet... Nane ve maydanoz... Gülüyorsunuz. Gülün, gülün. Elbet size de bir gülen bulunur."26

Buradaki kışkırtan anlatıcı farazi bir okur varlığını son derece ciddiye alarak gerçekten karşısında kendisiyle konuşan hatta atışan bir okur olduğunu varsaymaktadır. Anlatıcıyı kışkırtan okura gelince onu şu örnekte görmek mümkündür: "Pazar günleri İstanbul böyledir ama, gelin ben sizi eğlenceli bir yere götüreyim. Plajlarda serin mavi suların içine gömülmek, çam altlarında uyku çekmek dururken nereye gideceğiz?"27 Okur burada anlatıcıyla iş birliği yapmamakta ve onun isteğine uymamaktadır. İtiraz gerekçesini çürütmek anlatıcının işidir. Yazarı kışkırtan okurun varlığı başka bir yönüdür bu anlatıcının:

“Keşke Ramiz Bey’i aradığı gibi bir kez de karısını arasaydı. İncilâ Ferit'in sesini hiç olmazsa telefonda duysaydı. Hayır. Aramadı.

Niçin aramadı? Onu ben de bilmiyorum. Bir de derler ki, yazarlar yazdıkları kitapta yer alan kişilerin her halinden haberdar olur. Hadi canım sen de. ${ }^{2} 28$

Mustafa Kutlu'nun her yanı kışkırtan bu anlatıcı tipini analiz etmek çoğu zaman mümkündür; ancak yazar bazen o kadar girift bir anlatıma gitmektedir ki bu yüzden "yazar", “anlatıcı” ve “okur” arasında meydana gelen kaynaşma, kimin konuştuğunu ya da anlattığını tespit edilemez duruma getirmektedir:

"Pek anlaşılmadı Ali Balkan. Kalabalığa karışmak istemiyorsun çünkü seçkin birisin, bu tamam. Suna’ya namazını kıldığı için mi tutunmak istiyorsun? Bu da tuhaf, çünkü kızcağız beş vakit namazında değil. Seninle çıkacağını umut ettiği yolculukta İstanbul'u tanımanın âdabı olarak Eyüp Sultan Camii'ne girip iki rekât namaz kıld1. 'Yarabbi hakkımda hayırlı olanı nasip et' diye dua etti. Bu tutunamamak da neyin nesi? Tutunamamak aydın olmanın raconudur, bunu bilmen lazım yazar efendi." 29

İlk bakışta konuşanın anlatıcıyla okur olduğu sanılmaktadır, fakat arada söylenen bilgiler (Suna'nın beş vakit namaz kılmadığı, ne için dua ettiği gibi), anlatıcının ve en çok da yazarın bileceği konulardır. Anlatıcının her şeyi bilen bir anlatıcı olduğu varsayıldığında tarafların belli olduğu sanılmakta, ama sonunda

26 Mustafa Kutlu, Arkakapak Yazıları, İstanbul, Dergâh Yayınları, 2017, s. 36.

27 Sait Faik Abasıyanık, Havuz Başı, İstanbul, İş Bankası Yayınları, 2016, s. 49.

28 Mustafa Kutlu, Menekşeli Mektup, İstanbul, Dergâh Yayınları, 2017, s. 46.

29 Mustafa Kutlu, Sevincini Bulmak, İstanbul, Dergâh Yayınları, 2018, s. 175. 
“yazar efendi”ye hitap olunca bu konuşmanın üç eleman yani yazar, anlatıcı ve okur arasında geçtiği anlaşılmaktadır.

\section{Hikâyelerdeki Okur Benzerlikleri ve Farklılıkları}

Okur, yazarın sunduğu kurgusal gerçekliğin tek muhatabı olduğu için, yazarlar o yolda kendileriyle birlikte yürüyecek kişilerin de profillerini oluşturmaktadirlar. ${ }^{30}$ Kimi yazar okurunu pasifize edebilmekte, onun kurguya dahlini ya da hayal kurma yetisini kısıtlayarak bütün yolları ayan beyan göstermektedir. Kimi yazar ise okurunu anlatıya katıp zihnini ve hayal gücünü kışkırtarak onu kurgu labirentine sokmayı başarmaktadır. Yazar, bir nevi yalnızlığına bir yoldaş aramaktadır. Okurunu peşinden sürüklemeyi başaran yazar, ona her şeyi inandırma gücüne kavuşmuş kişidir aynı zamanda.

Sabahattin Ali, Sait Faik ve Mustafa Kutlu, okurunu belirleme konusunda tipik yazar özelliklerine sahip üç hikâyeci olarak zikredilebilir. Zira her biri, okur profilini oluşturma istekleri konusunda benzer özellikler arz etmektedir. Üç hikâyeci de bir muhataba/okura seslenme eğilimindedir. Ancak Sabahattin Ali'nin, diğer iki hikâyeciden farklı olarak okura daha mesafeli durduğunu söylemek mümkündür. Onun hikâyelerinde okuru muhatap alma eğilimi son derece kisitl1dır. "Bahtiyar Köpek" ve "Hakkımızı Yedirmeyiz!" adlı hikâyelere ait aşağıdaki iki örnek, Sabahattin Ali’nin okuruna sayılı hitaplarındandır:

"Niçin hep acı şeyler yazayım? Dostlar, yufka yürekli dostlar bundan hoşlanmıyorlar. "Hep kötü, sakat şeyleri mi göreceksin?" diyorlar. "Hep açlardan, çıplaklardan, dertlilerden mi bahsedeceksin? Geceleri gazete satıp izmarit toplayan serseri çocuklardan; bir karış toprak, bir bakraç su için birbirlerini öldürenlerden; cezaevlerinde ruhları kemirile kemirile eriyip gidenlerden; doktor bulamayanlardan; hakkını alamayanlardan başka yazacak şeyler, iyi güzel şeyler kalmadı mı? Niçin yazılarındaki bütün insanların benzi soluk, yüreği kederli? Bu memlekette yüzü gülen bahtiyar insan yok mu?’

Ah, ben hayvanları çok severim. Bütün canlı mahlukları, hayatı, güzelliği, saadeti severim. Bahtiyar bir köpek bile benim içimi sevinçle dolduruyor. Ben karanlık şeylerden bahsetmek için dünyaya gelmemişim. İçim tatlı, sıcak, neşeli şeyler anlatmak isteğiyle yanıyor. Hele cümle âlem bu köpeğin onda biri kadar rahata kavuşsun, bakın ben bir daha acı şeylerden söz açar mıyım?’’ı1

30 Serhat Demirel, “Modern Türk Şiirinde Okur Algıları (1860-1940)”, (Yayımlanmamış Doktora Tezi), Sakarya Üniversitesi Sosyal Bilimler Enstitüsü, Sakarya, 2019.

31 Sabahattin Ali, Sirça Köşk, İstanbul, Yapı Kredi Yayınları, 2017, s. 59, 62. 
"Namuslu adam kalmamış bu dünyada iki gözüm. Müslümandır, namazında, orucundadır, hakkımızı yemez diyorduk ama, biz onun hatırını saydıkça o, bizim tepemize bindi. Eh, artık çocuk değiliz, yemiyoruz bu numaraları, değil mi ya?.. ... Yerinden firladığı gibi gitti. Bizim yirmi papel de yandı tabii... Hadi, hepsi neyse ama, kapıdan çıkarken:

"Hesabı sen görüver, yanımda ufaklık yok!” diye seslenmesine ne dersin? Tepem attı vallahi. Utanmasam arkasından firlayacaktım. Hacıdır, hocadır; hürmet, riayet borcumuzdur ama, böyle göz göre göre de hakkımızı yedirmeyiz, değil mi ya..." 32

Her iki örnekte doğrudan bir okura hitap vardır, ancak dikkat çeken nokta, hikâyelerin başlarında ve sonlarında yer alan bu paragraflardır. Her birinde başta yapılan seslenme, hikâyenin sonunda yer alan paragrafta yinelenmektedir. Böylece Sabahattin Ali, hikâye başlarken yakaladığı okuruna, hikâyenin sonunda tekrar seslenerek onu uğurlamakta, bu sayede okur, doğrudan kendisinin muhatap alındığını düşünmekte, aynı zamanda değerli olduğunu hissetmektedir. Bu tavır da okurun hikâyeyi ve hikâyeciyi sahiplenmesini sağlamaktadır. Aralarında sadece edebî değil, dostlukla eş değerde bir arkadaşlık kurulmaktadır.

Sabahattin Ali'nin aleni bir şekilde okuruna seslenme ihtiyacı duymaması onun varlığını hesap etmediği anlamına gelmez. Onun okur tasavvuru "örnek okur" diye vasıflandırılacak tiptir. Anlatının içinde her şeyi anlatmak yerine boşluklar bırakmaktadır ve belli bir edebî birikime ve dikkate sahip olduğunu düşündüğü okurun o boşlukları doldurup hikâyeyi kendisiyle birlikte yeniden yazacağına inanmaktadır. Örneğin “Ayran” hikâyesinde Hasan, iki kardeşine bakabilmek için yaz kış her gün bir gügüm ayranı tren istasyonuna götürüp satmaya çalışmaktadır. Sabahattin Ali, karakterinin her gün yaptığı bu eylemine bir gün okurunu davet etmektedir. Okur, Hasan'la birlikte zorlu yolu aşıp istasyona ulaşmakta ve gitgide soğuyup kararan havada ekmek kavgasına tanık olmaktadır. Hasan hiçbir şey kazanamamanın üzüntüsüyle nihayet dönüş yoluna geçtiğinde geçmişini, hayatını, aç kardeşlerini ve annesini düşünmektedir. $\mathrm{O}$ anda okur annenin varlığından haberdar olmakta, hatta ne iş yaptığını ve yasal bir baba olmaksızın hepsinin dünyaya getirildiğini öğrenmektedir. Fakat bu bilgileri yazar ima yoluyla aktarmaktadır. Dikkatli okur, o boşlukları kendi bilgisiyle doldurup hikâyeyi bir nevi tamamlamaktadır. 
Mustafa Kutlu'nun Gönül İşi $i^{33}$ kitabında yer alan “Oy Dağlar” isimli hikâyesinde özellikle "örnek okur" tasavvuru görülmektedir. Çoğul anlatıcı dilinden aktarılan hikâyenin bölümleri Beser Gelin, eşi Ali Düzgün ve her şeyi bilen bir anlatıcı tarafından anlatılmaktadır. Gurbete giden Ali Düzgün'ün başına gelenler ve yıllar içerisinde yaşadığı dönüşümün izleri açıkça görülmektedir. Fakat o giderken Beser Gelin'in hamile olduğu yalnızca ima edilmektedir. Bunu fark etmek dikkatli ya da diğer adıyla "örnek okur"un işidir.

Sabahattin Ali'de görülen okur tavrının Sait Faik ve Mustafa Kutlu için geçerli olmadığ görülmektedir. Her iki hikâyeci de doğrudan okuruna seslenmeyi, onunla sohbet etmeyi, ona sorular sormayı sevmekte, dolayısıyla da s1k s1k kullanmaktadırlar.

Sait Faik, "Bugün dertli ve kimsesiz, otelin penceresinden geçen tramvaylara bakarken, niçin bu köy evine bir akşamüstü sessiz sedasız, bekleniyormuşuz gibi indiğimizin sebebini söylemeyeceğim" 34 ya da "Ben ne hain bir burjuva çocuğuydum, bilemezsiniz" ${ }^{35}$ cümleleriyle bir oyunun hazırlıklarına girişmektedir. Bildiği şeyleri söylememek yoluyla okurunu merakta bırakmayı hedeflemektedir. Okur, kendisinden saklanan sırrı öğrenene kadar yine yazarın peşini bırakmayacaktır. Aynı tavrı "Beklediğimin gelmediği günlerden bahsedecek değilim" cümlesiyle sürdürmektedir.

Sait Faik bazen okurunu ortada birakabilmektedir. "Garibi iyi Rumca, daha tuhafı çok fena Almanca konuşur. Nereden, nasıl öğrenmiştir? Ne bileyim ben"37 dediği zaman, anlatıcının her zaman her şeyi bilemeyeceğini göstermektedir, ama bu da bir oyundur. Önemli bir şeye varılacakmış hissi veren yola sokmaktadır okurunu, sonra da orasının bir çıkmaz sokak olduğunu belli etmektedir. Anlatıcı -tabii çoğunlukla bu anlatıcı Sait Faik'tir- görünüşe göre önemsiz bir konuyu belirtmektedir; önemli olan kısım yabancı dillere hâkimiyettir. Okurun bununla yetinmeyip ötesini merak etme olasılığına karşın Sait Faik onun adına meseleyi zihninde sürdürmekte ve hayalî sorunun önünü kesmektedir. Bir yandan "Sevgili okur, bu konu önemsizdir" diyor gibi gözükürken diğer yandan da cevabını bulamayan sahipsiz bir soruyu ortaya atıp yanıtını okurunun bulması için yol göstermektedir. Sait Faik ne tür bir oyunun içine okurunu dâhil ettiğini şöyle ortaya koymaktadır:

33 1970'te yayımlanan ilk hikâye kitabı. Onun ve bir sonraki kitap olan Ortadaki Adam'ın yeni baskılarına Kutlu müsaade etmemektedir.

34 A.g.e., s. 33.

35 A.g.e., s. 48.

36 A.g.e., s. 93.

37 A.g.e., s. 101. 
"Siz bir adamı hiç görmeden, iki dakika evvel öyle bir adamın İstanbul ilinde yaşadığını bile bilmeden, birdenbire zanaatından ve adından seviverdiniz mi? İçinizi hiç bilmediğiniz bir İstanbul semtinin akşamı kaplarken ve evinin önünde oturup sigara içen, gözkapakları kirpiksiz ve kıpkırmızı ihtiyar bir adamı hayranlıkla, sevgiyle, saygıyla andınız mı? Hiç içinize taş gibi, ağır bir su gibi bir sevgi oturdu mu? Oturmamışsa Allah aşkına vazgeçin şu yazımı okumaktan." 38

Görüldüğü gibi Sait Faik, herkesi okur sınıfına kabul etmemektedir. Belirli kriterleri yerine getirmeyenlerle işi olmadığı gibi, onlara anlatacak bir hikâyesi de yoktur. Bu durumda Sait Faik’in, hikâyeleri için belli özelliklere sahip okurlar aradığını söylemek mümkündür.

Sait Faik başka türlü oyunlar da oynar okuruyla. Alıştırdığı gerçekliği bir anda yok ederek okurunu bir birden ortada bırakabilir veya tuhaf kabul edilebilecek şeylere inanmasını bekleyebilir ondan:

"Kırlangıç yuvasına kadın sığar mı demeyin. İnsan aklına sığan şeyleri bir yol hayal buyurun. Kırlangıç yuvasına bir kadın sokmuşuz, saçlarını, ıslak saman rengi saçlarını tarar dururmuş. Ne zararı var size? ... İstersem kırlangıç yuvasına bir kadın oturtur, saçlarını taratırım. İstersem kırlangıç yuvasına ateşböceğinden bir avize takarım, istersem kırlangıçla yuvasındaki kadına, sanki günahmış gibi, günah işletirim bu ışığın altında. Derim ki, bir kırlangıç, bütün bir yaz ayı boyunca tam iki milyara yakın kumuç, tatarcık, sinek avlar. Ne dersem derim. Kimsecikler karışmaz. Birçokları sevinirler de, insanoğlunun insanoğluna yaptıklarını görüp de anlatmadığıma... Ne yapayım, benim zanaatım da bu, yazı yazmak. Yazı yazıp ekmek yemek. Yazmak demek, aklıma ne gelirse kâğıda geçirmek değil elbet. Ama ben aklıma ne eserse yazan cinsindenim, ne yapayım?"39

Okura seslenme, onu muhatap kabul etme özelliği, Mustafa Kutlu hikâyelerinde çok daha etkili bir unsurdur. Öyle ki bazen yazar ve anlatıcı arasında bir çatışma meydana getirilir ve okurun taraf olması beklenir:

"Bu kadar efendim. Varsın kızla oğlan birbirlerini o güne kadar görmemiş olsun. Varsın kızla Postacımızın arasında bir on beş yaş fark olsun.

Hop, hop. Orada dur bakalım. On beş yaş mı dedin. Evet öyle, ne var bunda? Amca diyor ki, ben de eşimi aldığımda kendisi on üçten on dörde yeni adım atmıştı, kendim otuza doğru gidiyordum. Yeter ki iki gönül bir olsun.

38 Sait Faik Abasıyanık, Son Kuşlar, İstanbul, İş Bankası Yayınları, 2017, s. 43.

39 A.g.e., s. 114-116. 
Olsun olsun da, nasıl olacak? O dediğin hadiseler çok geride kaldı.

Şimdi köylük yerin kızı da olsa kimsenin gözü kapalı değil. Yazık kızcağıza. Elâlem ne der? Üç kuruşa kızı sattılar der. Böyle giderse, yani biz bu işin altını üstünü bu kadar mıncıklarsak, pişmiş aşa su katacağız. Ne lüzumu var. Olanla ölenin hesabı sorulmaz. Geçelim efendim, geçelim. Geçtik." ${ }^{40}$

Örnekte görüldüğü gibi anlatıya yazar tarafından bir müdahale söz konusudur. Anlatıcı dizginleri eline alıp okur namına yazardan hesap sorabilmektedir. Mustafa Kutlu da tıpkı Sait Faik gibi bir okur tasarımı oluşturmaktadır. Fakat Kutlu, Sait Faik'ten daha kontrolcü davranmaktadır. Hatta işi şansa bırakmayıp doğrudan müdahale etmektedir:

“Aziz okuyucu, burada şunu söylemeliyim. Yazar kahramanlarına karş1 âdil olmalıdır. Düşeni kaldırmalı.

Ne yani, açıkça taraf tutmalı, öyle mi?

Hayır. Yanlış anlama. Düşeni kaldıracak ki macera devam etsin. Roman, hikâye, filim senaryosu böyledir. Okuyucu veya seyirci de bunu ister. Yarım kalmış bir serüven kimseyi doyurmaz.

Anlaşıldı. Düşeni kaldırmalı ama âdil olduğu sanılmalı. Okuru keriz yerine koymak oluyor bu. Herkes bilir ki kahramanın ipi yazarın elindedir.

Hayır. Kahramanın birinci özelliği "Kendisi olması"dır. Bıçak sırtı bir iştir bu. Kahramanı serbest bırakırsan yoldan çıkar, başına iş açar."

Örnekte görüldüğü üzere Mustafa Kutlu, sorgulayan, gerektiğinde yazarı hesaba çeken bir okurun profilini açıkça oluşturmaktadır. Bu hâliyle yazar ve okur arasında bir suç ortaklığından söz etmek mümkündür.

Sait Faik gibi Mustafa Kutlu da okurunu sorularla k1şkırtmaktadır. "Bunu tam yanlarından geçerken sendeleyip Engin'in kucağına yığılmasından çıkarıyoruz. Gazetecinin nasıl bir hinoğlu hin olduğunu anlatalım mı?"42 cümlesi bir muhatabı çağırmaktadır hikâyeye.

Mustafa Kutlu için mevcut okur tiplerinin yanı sıra yeni bir tane önerilebilir: "Pastoral okur". Bu okur, tabiatı reddetmeyen, ondan uzakta kaldıkça mutsuzlaşan, ona yaklaştıkça birçok sorunu çözdüğünü sanan bir okurdur. Mustafa Kutlu hikâyelerinde tabiat, dekorun önemli bir parçasıdır. Bu tutkusunu yazarın kendisi

40 Mustafa Kutlu, Menekşeli Mektup, İstanbul, Dergâh Yayınları, 2017, s. 10.

41 Mustafa Kutlu, Sevincini Bulmak, İstanbul, Dergâh Yayınları, 2018, s. 164-165.

42 Mustafa Kutlu, Yoksulluk İçimizde, Dergâh Yayınları, İstanbul 2017, s. 82. 
de fark etmiş olmalı. Özellikle son hikâye kitabı Sevincini Bulmak'ta karakterlerini büyük şehirden tabiata gönderdiğinde karakterlerden biri bu takıntıya itiraz etmektedir. Dolayısıyla Kutlu için önerilebilecek bu okur tipi, onun hikâyeleri için son derece ideal bir tiptir.

Mustafa Kutlu anlatıcıları ve okur algısı Sait Faik'inkileriyle yakınlık arz eder. Buna rağmen Kutlu'nun, yepyeni bir anlayışa girdiği görülmektedir. Özellikle ilk iki hikâye kitabından (Ortadaki Adam ve Gönül İşi) son hikâye kitabına (Sevincini Bulmak) kadar yaşadığı macerasında okuruyla sohbet etmeye, onu kurguya dâhil etmeye, hatta karakterlerini yazara müdahale etmeye yönlendirmesinin gitgide güçlendiği görülmektedir. Anlaşılan o ki, böylesi bir yazım dilinin hem kışkırtıcı hem de kuşatıcı bir yönü bulunmaktadır. Bir kez okuru görünür hâle getiren yazarlar, ondan kolay kolay kurtulamazlar:

"Biliyorsunuz aslında ben Süheylâ’nın hikâyesini bitirmiştim. Yani kendi hesabıma sevgilisi Engin onu terk edip de kara-kuru ancak fevkalade zengin biri ile nişanlanınca artık bitti bu hikâye demiştim. Ama hayat tesadüflerle doludur. Bir gün yeniden Süheylâ ile karşılaşacağımı nereden bilebilirdim..."43

Mustafa Kutlu, bazen okurdan ziyade kahramanlarını sahiplenir. Örneğin Kambur Hafız karakterini, bir hikâyesinden çıkarıp yazarın yani kendisinin karş1sına dikip hesap sormasını engellememektedir. Kutlu bazen de okurun anlatıyı ele geçirmesine göz yummaktadır:

"Kafamız karıştı sayın Kutlu. Cinsellik aşkı kirleten bir şey değil ki; hayatın kanunu böyle. Aksine yatak odası uyumlu olan, hele ki bir de çocuğa kavuşan çiftlerin aşkı ikiye katlanırmış, derler. Senin söylediğin umuma aykırı bir durum. Pek de kabul edilecek bir yanı yok yani.

Tamam, kabul. Postacı kimselere benzemiyor. Kimselere benzememenin ölçüsünü kaçırdığ için onu hasta bile sayabiliriz. Elbette hasta saymak lazım gelir ve bir an önce doktora başvurmaları lazım gelir.

Postac1, "Ey bu kitabı okuyanlar benim bu laflara karnım tok, sizinle laf yarıştırmaya da hiç niyetim yok" deyip kulağının üzerine yattı." ${ }^{\text {"4 }}$

Bu tavrı sanatsal bir eylem olarak kabul etmek mümkün gibi görünse de Kléber Haedens'in romancılar için söylediği fakat buradaki durumda uzun hikâye yazarları için de yerinde tespitler olarak görülen şu sözleri önemlidir: 
"Romancının on gramlık muhayyilesi varsa yazarken aklına yeni fikirler gelir, hikâyesinden uzaklaşır., kahramanlarına yeni hususiyetler verir; böylece, eşsiz bir iyilik timsali olan bir şahıs biraz kötüleşir, şapşallığın timsali bir diğeri de sanıldığından daha kurnaz çıkar. Romancılar o zaman kendilerini böyle yol değiştirmeye zorlıyan bizzat kahramanları olduğunu ileri sürerler. Bu doğru değildir, fakat yazarın koltuklarını kabartır. O kadar canlı insanlar yaratmıştır ki kendisinin de elinden fırlayıp kurtulmaktadırlar.

Hakikatte ne olmuştur? Romanını "hazırlıyan" romancı ister istemez sathî bir iş görmüştür. Kahramanlarının hareketlerini son neticelerine kadar takibetmiş değildir. Yazdığı zaman, işi ne de olsa biraz daha yakından görür. İlkönce yarım yamalak sezmiş olduğu bir fikir, bir hareket, yeni bir 1şığa bürünmüş olarak karşısına çıkar. Bunların taşıdığı mâna derinleşir, romancı da bunu kahramanlarının kudretine atfederek pek zevk duyar. Hakikatte şahısların bu zâhirî istiklâlleri romancının işine daha devamlı bir dikkatle girişmiş olmasından ileri gelir." 45

$\mathrm{Bu}$ tespitler, karakterlerin yazara veya anlatiya müdahalesini bir yetkinlik olarak değil, "az çalışmışlık" olarak ortaya koymaktadır. Yazar bu eksiklik nedeniyle karakterlerini kontrol etmekte zorlanmaktadır. Mustafa Kutlu'da görülen müdahale meyli, sadece anlatıcının ya da okurunki olarak algılanmamalıdır. Yeri geldiğinde yazarın müdahalesi de söz konusudur. O vakit, yazar olarak Mustafa Kutlu'nun yerinin pekiştirildiği, okurun ve anlatının üzerinde tek hâkimiyet sahibi olduğu vurgulanmaktadır. Son hikâye kitabı Sevincini Bulmak'ın bitirilişi, okura ve hikâye karakterlerine fazla yetki vermenin girift sonucunu gözler önüne sermektedir. Kontrolün kimde olduğu sorusu, neticesiz kalacak bir arayıştır:

“Hem şu yazdığın kitabın hem benim selametim için bir teklifim var.

Nedir?

Sen, ben, okur bir oturum yapalım.

Sebep?

İstikbalimden endişe ediyorum. Bu macera daha ne kadar sürecek? Piyasa kalın kitap istiyormuş. Oysa ben Taşoluk’taki hayatımdan memnunum. Lütfen bir nokta koyalım. Beni bana bırakın. Uzatmayın.

Yazar: Artık bu kitaba devam etmenin bir anlamı kalmadı.

45 Kléber Haedens, Roman Sanatı, çev. Yaşar Nabi, Ankara, Varlık Yayınları, 1953, s. 57. 
Okur: Olur mu efendim? Biz merakla, zevkle okuyor, sonu nereye varacak acaba diyorduk.

Yazar: Ama Suna Hoca istemiyor, yeter dedi.

Okur: Kahraman yazara başkaldırdı diyorsun, saçmalık bu.

Yazar: Hayır. Bana nerede durmam gerektiğini ihtar ediyor. Uydur, uydur yaz. Bir yere kadar."46

Mustafa Kutlu'nun izlediği yol, rahat bir üslup olarak görülebilir ve bu, okura, hatta yazarın kendisine hızla sirayet eden ve kontrol altına alan bir yöntemdir. Hem taklit edilme olasılığını kuvvetlendirmekte hem de yazarın bu girdaptan kurtulamayıp yeni bir ses bulmasını zorlaştırmaktadır. Kutlu'nun sıkça başvurduğu bu yöntem, yine de ona has bir üslup oluşturmaktadır.

\section{Sonuç ve Değerlendirme}

Sabahattin Ali, Sait Faik ve Mustafa Kutlu'nun benzer anlatıc1lar olarak "tanrısal anlatıcı", "ben-anlatıcı", "yazar-anlatıcı" ve çerçeve anlatıların "dış-iç anlatıcı"larını kullandıkları görülmektedir. Üç hikâyecide benzerlik olarak "ben-anlatıcı" (özellikle Sait Faik ve Mustafa Kutlu'da) dikkati çekmektedir. Sabahattin Ali, Sait Faik ve Mustafa Kutlu, okurun gözünde anlatıcı olarak kendilerinin görülmesinden endişe duymazlar. Hikâyelerinde, yazarların birebir gözlemleri oldukları hissi ağır basar. Ayrıca anlatıcıya verdikleri isimler, vasıflar, yazarın kendi kimliğiyle örtüşmektedir.

Sabahattin Ali ve Sait Faik arasındaki benzerlik, Mustafa Kutlu'da başka bir şekil alır. Onun hikâyelerinde geçen "ben-anlatıcı"ları yazarın kendisiyle bağdaştırmak mümkün değildir. Elbette yazara atıfta bulunanlar mevcuttur, ama bunlar azınlıktadır. Kutlu'nun sonraki yıllarında daha çok başvurduğu uzun hikâye yazma meyli, zaman zaman roman yoluna girmesi sebebiyle, birkaç anlatıcının ortaya çıkmasına sebep olmuştur. Bazen karakterlerin ağzından bazen ilahî bakış açısıyla anlatılan hikâye, kimi zaman çoğul anlatıcı hüviyeti kazanmaktadır. Çoğul anlatıcı tipi Sait Faik’te de görülür, ancak Sabahattin Ali'de yoktur.

Sait Faik ve Mustafa Kutlu için ortak bir anlatıcı tipi olarak "meddah anlatıcı" önerilebilir. Her iki hikâyeci de okurlarıyla sohbet etmekten son derece büyük zevk almaktadırlar. Bu anlatıcı tipi, hem Sait Faik hem de Mustafa Kutlu hikâyeciliği için son derece uygundur. Sabahattin Ali'den ve Sait Faik'ten ayrı olarak Mustafa Kutlu'da dikkat çeken bir anlatıcı tipi de "kışkırtan anlatıcı" tipidir. Kutlu, okuruyla konuşmanın sınırlarını o kadar genişletir ki, bu sohbetlerin dahi

46 Mustafa Kutlu, Sevincini Bulmak, İstanbul, Dergâh Yayınları, 2018, s. 294-296. 
kendi içinde ayırıcı vasıfları ortaya çıkar. Okuru kışkırtan anlatıcı, Kutlu'nun kışkırtan anlatıcısının başka bir yönüdür.

Sabahattin Ali, Sait Faik ve Mustafa Kutlu, okur profilini oluşturma konusunda ortaktırlar: Üç hikâyeci de bir muhataba/okura seslenme eğilimindedir. Ancak Sabahattin Ali'nin, diğer iki hikâyeciden farklı olarak okura daha mesafeli durduğunu söylemek mümkündür. Sabahattin Ali'nin okur tipi “örnek okur"dur. Sabahattin Ali'de görülen okur tavrının Sait Faik ve Mustafa Kutlu için geçerli olmadığ1 görülmektedir. Her iki hikâyeci de doğrudan okuruna seslenmeyi, onunla sohbet etmeyi, ona sorular sormayı sevmekte, dolayısıyla da sik sık kullanmaktadırlar.

Sabahattin Ali, Sait Faik ve Mustafa Kutlu'da kendini gösteren anlatıcı ve okur çeşitliliği, benzerlikten çok farklılıklara sahip bir yapı olarak ortaya çıkar. Görülen o ki, yolun başlangıcında yer alan Sabahattin Ali'den diğer iki hikâyeci etkilenmiştir, fakat bu etki, bir taklitten ziyade Sait Faik ve Mustafa Kutlu'ya özgü bir üsluba dönüşmüştür. Sait Faik' in canı istediği zaman anlatıya müdahale eden ve kendisinden başkası olmayan "ben-anlatıcıs1", okurun metni benimsemesini, ona sahip çıkmasını, ama en önemlisi ona yol boyunca eşlik etmesini sağlamaktadır.

Mustafa Kutlu anlatıcıları ve okur alg1sı Sait Faik'inkileriyle yakınlık arz etmektedir. Buna rağmen Kutlu'nun, yepyeni bir anlayışa girdiği görülmektedir. Mustafa Kutlu, bazen okurdan ziyade kahramanlarını sahiplenir. Hatta karakterini, bir hikâyesinden çıkarıp yazarın yani kendisinin karşısına dikip hesap sormasını engellemez. Bazen de okurun anlatıyı ele geçirmesine göz yumar. Bu tavrı sanatsal bir eylemdir, ancak bu yüzden bazen karakterlerini kontrol etmekte zorlanır. Kutlu'daki müdahale meyli, anlatıcıya, okura ve yazara sirayet eder. Okuru da yazarı da kontrol altına alan bu yöntem, Kutlu'ya has bir üslup oluşturmakta, aynı meyilde yazmaya kalkışan herkesin "Kutluvari” mührüyle işaretlenmesine sebep olmaktadır. 


\section{Kaynakça}

Abasıyanık Sait Faik, Alemdă̆'da Var Bir Yılan, İstanbul, İş Bankası Yayınlar1, 2014.

, Havada Bulut, İstanbul, İş Bankası Yayınları, 2017. , Havuz Başı, İstanbul, İş Bankası Yayınları, 2016. , Mahalle Kahvesi, İstanbul, İş Bankası Yayınları, 2000. , Sarnıç, İstanbul, İş Bankası Yayınları, 2017. , Semaver, İstanbul, İş Bankası Yayınları, 2018. , Son Kuşlar, İstanbul, İş Bankası Yayınları, 2017. , Şahmerdan, İstanbul, İş Bankası Yayınları, 2017. , Tüneldeki Çocuk, İstanbul, İş Bankası Yayınları, 2016.

Ali, Sabahattin, Değirmen, İstanbul, Yapı Kredi Yayınları, 2017. , Sırça Köşk, İstanbul, Yapı Kredi Yayınları, 2017.

Aristoteles, Poetika, çev. İsmail Tunalı, İstanbul, Remzi Kitabevi, 2002.

Aslan, Bahtiyar, "Mustafa Kutlu Hikâyelerinde Yazar-Anlatıcı ve Okuyucu Diyaloğunun İşlevlerinden Biri: Yazarın Kendi Okuyucusunu Yaratması", içinde: Aynanın Sırrı: Mustafa Kutlu Sempozyum Bildirileri, İstanbul, 2012.

Barthes, Roland, Anlatıların Yapısal Çözümlemelerine Giriş, çev. Mehmet Rifat-Sema Rifat, İstanbul, Gerçek Yayınevi, 1988.

Can, Bilal, "Mustafa Kutlu Öykücülüğünde Mekân: Bir Edebiyat Sosyolojisi İncelemesi", (Yayımlanmamış Yüksek Lisans Tezi), Dumlupınar Üniversitesi Sosyal Bilimler Enstitüsü, Kütahya, 2015.

Cevizci, Ahmet, Felsefe Terimleri Sözlüğ̈̈, İstanbul, Paradigma Yayınları, 1999.

Demir, Yavuz, Illk Dönem Türk Hikâyelerinde Anlatıcılar Tipolojisi, İstanbul, Dergâh Yayınları, 2002.

Demirel, Serhat, "Modern Türk Şiirinde Okur Alg1ları (1860-1940)", (Yayımlanmamış Doktora Tezi), SAÜ SBE, Sakarya, 2019.

Forster, E.M., Roman Sanatı, İstanbul, Milenyum, 2019.

Haedens, Kléber, Roman Sanatı, çev. Yaşar Nabi, Ankara, Varlık Yayınları, 1953. 
Hafiz, Muharrem, “Platon, Aristoteles ve Plotinus'ta Mimesis Teorisi”, İslâmî Araştırmalar, c. 26, s. 1, İstanbul, 2015.

Kutlu, Mustafa, Anadolu Yakası, Dergâh Yayınları, 2017. , Arkakapak Yazıları, İstanbul, Dergâh Yayınları, 2017. , Mavi Kuş, İstanbul, Dergâh Yayınları, 2017. , Menekşeli Mektup, İstanbul, Dergâh Yayınları, 2017. , Ortadaki Adam, İstanbul, Dergâh Yayınları, 1970. , Sevincini Bulmak, İstanbul, Dergâh Yayınları, 2018. , Yoksulluk İçimizde, İstanbul, Dergâh Yayınları, 2017. , Zafer Yahut Hiç, İstanbul, Dergâh Yayınları, 2017.

Stevick, Philip, Roman Sanatı, çev. Sevim Kantarcıŏlu, Ankara, Akçağ Yayınları, 2017.

Şen, Pelin, "Platon'un Mimesis Kavramı Üzerine Bir İnceleme”, Eskişehir, AÖF, 2012.

Tekin, Mehmet, Roman Sanatı-Romanın Unsurları I, İstanbul, Ötüken Yayınları, 2001.

Uzun, İbrahim, “Aristoteles'in Katharsis ve Mimesis Kavramlarının Analizi ve Değerlendirilmesi”, https:// www.academia. edu/ 5688285. Erişim tarihi: 20.09.2019.

Yücebaş, Hilmi, Bütün Cepheleriyle Sait Faik: Hayatı/Hatıralarl/Eserleri, İstanbul, İnk1lâp Kitabevi, 1964. 